\title{
Distribution and Multiplication of Ralstonia solanacearum (Synonym Pseudomonas solanacearum) in Tomato Plants of Resistant Rootstock Cultivar LS-89 and Susceptible Ponderosa
}

\author{
Kazuhiro NAKAHO*
}

\begin{abstract}
We examined the distribution and multiplication of Ralstonia solanacearum (Synonym Pseudomonas solanacearum) in roots and stems of tomato plants of resistant rootstock cultivar LS-89 and susceptible cultivar Ponderosa. In a growth chamber at $30^{\circ} \mathrm{C}, 30$-day-old seedlings were inoculated with $R$. solanacearum strain $8107 \mathrm{~S}$ after trimming lateral roots and immersing the root ball in a bacterial suspension of $10^{7} \mathrm{cfu} / \mathrm{ml}$. In inoculated Ponderosa plants, bacteria were recovered from all taproot and stem samples tested. Pathogen density increased in root and stem tissues to $10^{8}$ or $10^{9} \mathrm{cfu} / \mathrm{g}$ fresh matter in 10 days. Inoculated LS. 89 plants were latently infected with the pathogen. Recovery of the pathogen in these LS-89 plants at 14 days after inoculation was about $90 \%$ in taproots and the upper hypocotyls, and about $80 \%$ in the first internodes, but the percentage decreased higher in the stem $(30 \%$ recovery at the fifth internode). Pathogen density increased to $10^{6} \mathrm{cfu} / \mathrm{g}$ fresh matter in taproots, upper hypocotyls and the first internodes in the first 4 days, but it was steady afterwards. Transverse sections of the upper hypocotyls of infected plants showed bacterial masses in the primary and secondary xylem tissues in Ponderosa, but only in a portion of the primary xylem tissues in LS-89. These results indicate that the bacteria are localized in the primary xylem tissues and their movement is limited in resistant LS- 89 plants.
\end{abstract}

(Received July 10, 1996 ; Accepted December 27, 1996)

Key words : Ralstonia (Pseudomonas) solanacearum, tomato, resistance, rootstock.

\section{INTRODUCTION}

Bacterial wilt caused by Ralstonia solanacearum (Synonym Pseudomonas solanacearum $\left.{ }^{20}\right)$, distributed widely in tropical, subtropical and some warm temperate regions worldwide, is one of the most important diseases of solanaceous crop plants ${ }^{8}$. As the most successful method of control for bacterial wilt is the use of resistant cultivars ${ }^{16)}$, several highly resistant tomato rootstocks have been developed in Japan ${ }^{12,21}$. Grafting of susceptible tomato cultivars onto resistant rootstocks has been adopted to manage bacterial wilt ${ }^{11,12,211}$.

In our previous report ${ }^{13)}$, plants of the resistant rootstock cultivar LS-89 (Lycopersicum esculentum) which were inoculated with $R$. solanacearum after trimming the lateral roots, and immersing the root ball in bacterial suspension, showed latent infection or mild wilting. When scions of the susceptible cultivar Ponderosa ( $L$. esculentum) grafted on LS-89 rootstocks were similarly inoculated with the pathogen, many Ponderosa scions had infection with the pathogen moved from latently infected LS- 89 rootstocks and wilted.

To clarify the mechanism of bacterial wilt resistance in LS-89, this paper reports precisely on the distribution and density of $R$. solanacearum in root-inoculated plants of resistant LS-89 and susceptible Ponderosa and on the movement of the pathogen in their stems.

\section{MATERIALS AND METHODS}

Plants Resistant tomato LS- $89^{21)}$ and susceptible Ponderosa were used. Tomato cultivars were individually seeded in peat moss pellets (Jiffy-9, $50 \mathrm{~mm}$ single, Jiffy Products Ltd.) in a greenhouse at $25 \pm 5^{\circ} \mathrm{C}$. About 30 days after sowing, seedlings of LS. 89 having five to six leaves and those of Ponderosa having four to five leaves were inoculated.

Bacteria $R$. solanacearum strain $8107 \mathrm{~S}$, which is a fluidal spontaneous mutant from the strain $8107^{13}$ and resistant to $200 \mu \mathrm{g} / \mathrm{ml}$ streptomycin sulfate, was used to permit sensitive counting of bacterial colonies on the selective agar medium described below ${ }^{7)}$. Antibiotic resistance of $8107 \mathrm{~S}$ remained stable after its recovery from infected tomato plants. Pathogenicity of $8107 \mathrm{~S}$ to tomatoes is essentially similar to 8107 . Symptoms caused by $8107 \mathrm{~S}$ in LS- 89 is a little milder than those by 8107 , but the density of 8107 and $8107 \mathrm{~S}$ in latently infect.

\footnotetext{
* Chugoku National Agricultural Experiment Station, Nishifukatsu, Fukuyama 721, Japan中国農業試験場
} 
ed LS-89 tissues in our preliminary study did not differ. Cultures were stored in a solution of $100 \mathrm{~g}$ skimmed milk and $10 \mathrm{~g} \mathrm{Na-glutamate} \mathrm{per} \mathrm{liter} \mathrm{at}-20^{\circ} \mathrm{C}$ to avoid possible development of non-pathogenic mutants.

Inoculation The stock culture was thawed and streaked on the selective agar medium of Hara and Ono $^{7)}$ containing $200 \mu \mathrm{g} / \mathrm{ml}$ streptomycin sulfate. After incubation at $30^{\circ} \mathrm{C}$ for $48 \mathrm{hr}$, bacteria were collected using a plastic spatula and suspended in distilled water. The suspension was diluted further with water to have bacteria at $10^{7} \mathrm{cfu} / \mathrm{ml}$ as estimated with a colorimeter $\left(O D_{660}=0.22: 5 \times 10^{8} \mathrm{cfu} / \mathrm{ml}\right.$, Spectronic 20, Bausch \& Lomb). Tomato seedlings were inoculated by trimming lateral roots extending from peat moss pellets, then immersing the pellets in the bacterial suspension in a plastic container $(34 \times 24 \times 15 \mathrm{~cm})$ for $24 \mathrm{hr}$ in a growth chambers under 30,000 lux light for $12 \mathrm{hr}$ per day at constant temperature of $30^{\circ} \mathrm{C}$. Sixty to 96 plants of each LS-89 and Ponderosa were used per treatment. The experiment was repeated eight times. Inoculated plants were grown in the growth chamber under the same conditions.

Recovery of bacterial pathogens from plant tissues Inoculated plants of LS-89 and Ponderosa were indexed daily for 14 days for disease severity following the numerical grading of Winstead and Kelman ${ }^{19)}$. Daily for the first 10 days and on the 14th day after the inoculation, plants were sampled randomly by dissecting 5-mm-long sections from taproots, upper hypocotyls (approximately $5 \mathrm{~mm}$ below the cotyledon) and the first, third and fifth internodes of seedlings. Sections were separately weighed and macerated with $1 \mathrm{ml}$ of sterile distilled water using aluminum sticks in a test tube (1.5 $\mathrm{cm}$ in diameter and $10.5 \mathrm{~cm}$ long). After incubation of the samples in the test tube at $10^{\circ} \mathrm{C}$ for $12 \mathrm{hr}$ to allow bacteria to ooze and disperse in the water, $100 \mu 1$ of the tissue suspension were diluted serially and plated onto the selective agar medium ${ }^{7}$ amended with the antibiotic. The plates were cultured at $30^{\circ} \mathrm{C}$ for $48 \mathrm{hr}$. Seedlings of the two cultivars mock-inoculated with distilled water served as the control. Colony number was counted and converted to indicate bacterial density in tissues in $\mathrm{cfu} / \mathrm{g}$ of fresh matter (cfu/g FM).

Statistical analysis The Scheffe's F-test and the Fisher's exact probability test were used in analysis on pathogen density and pathogen recovery, respectively.

Light microscopy Fourteen days after inoculation, latently infected LS-89 plants and totally wilted Ponderosa plants were selected. A 5-mm-long section was sampled from the upper hypocotyl of each plant and fixed in a mixture of formalin, acetic acid and $50 \%$ ethanol ( $1: 1: 18$ in volume) for $48 \mathrm{hr}$ or longer. The fixed section was dehydrated through an ethanol and 1 . butanol series and embedded in paraffin. Transverse sections, $15-20 \mu \mathrm{m}$ in thickness, were obtained from embedded sections mounted on a rotary microtome and

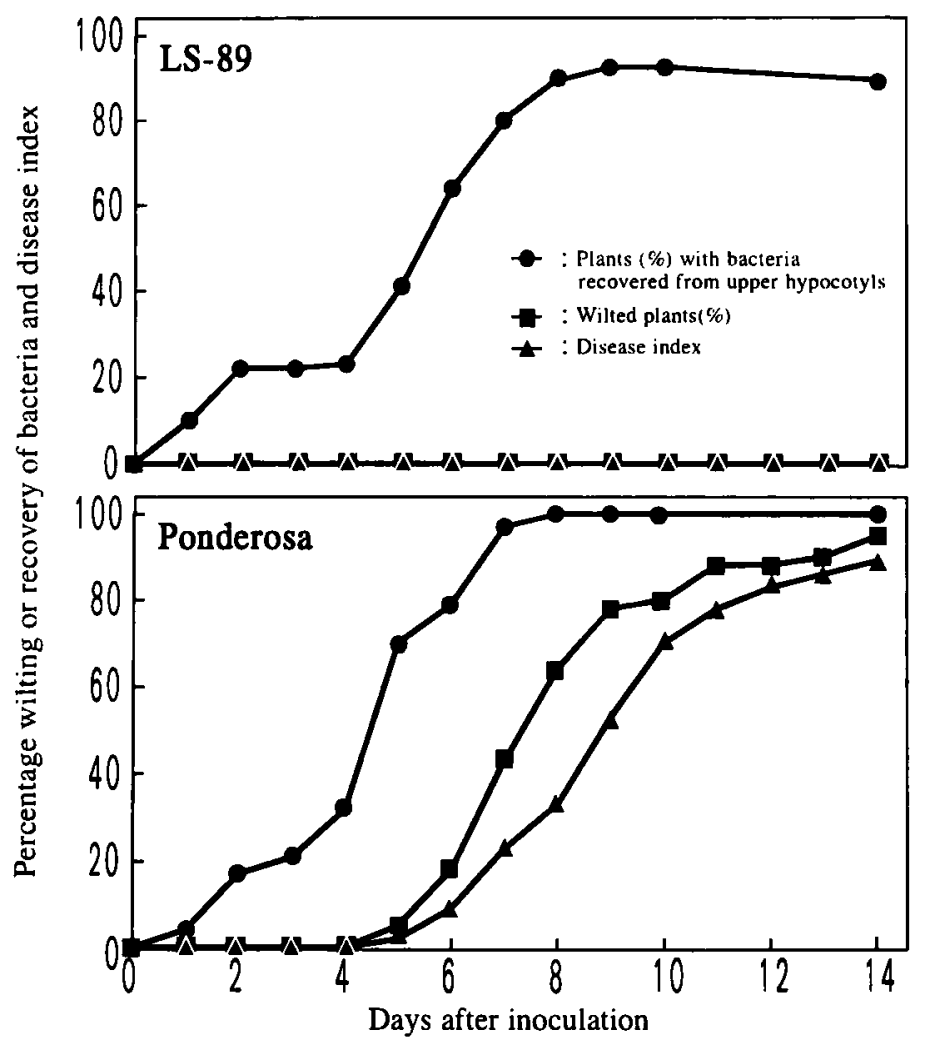

Fig. 1. Percentage of wilting, percentage of recovery of the pathogen from upper hypocotyls, and disease severity index of seedlings of LS.89 and Ponderosa from 1 to 14 days after inoculation with Ralstonia (Pseudomonas) solanacearum $8107 \mathrm{~S}$. Percentage of wilting and bacterial recovery in upper hypocotyls and disease index were monitored on 9-12 randomly selected plants. Average of five replications. 
stained with thionin and orange $\mathrm{G}^{15}$. Accordingly, bacterial masses were stained purple, lignified cells blue and parenchymatous cells yellow to orange. Thin sections were observed under a light microscope to locate bacterial masses in the stem tissues.

\section{RESULTS}

\section{Recovery of the pathogen and conditions of inoculated plants}

In Ponderosa, the pathogen was recovered from plants by 1 day after inoculation. Leaf wilting had begun by 5 days after inoculation (Fig. 1). By 7 days after inoculation, the percentage of pathogen recovery and the per. centage of wilting in inoculated plants increased over time and had reached nearly $100 \%$ by 7 and 14 days after inoculation, respectively. By 14 days after inoculation, almost all inoculated plants showed severe wilting or death. In LS-89, the increase in the percentage of pathogen recovery was similar to that in Ponderosa, although none of inoculated plants showed wilting.

Distribution and density of the pathogen in plants of LS-89 and Ponderosa

In inoculated LS- 89 plants, pathogen density increased to $10^{6} \mathrm{cfu} / \mathrm{g} \mathrm{FM}$ in taproots, the upper hypocotyls and the first internodes in the first 4 days after inoculation, then steadied (Fig. 2). The density in the third internode remained at a low level even at 10 days after inoculation $(p<0.05)$. However, in inoculated Ponderosa plants, pathogen density in all the parts increased with time after inoculation and reached $10^{8}$ or $10^{9} \mathrm{cfu} / \mathrm{g} \mathrm{FM}$ by 10 days (Fig. 2). At 10 days after inoculation, the density was significantly higher in all parts of Ponderosa than in LS-89 $(p<0.05)$.

At 14 days after inoculation, bacteria were recovered

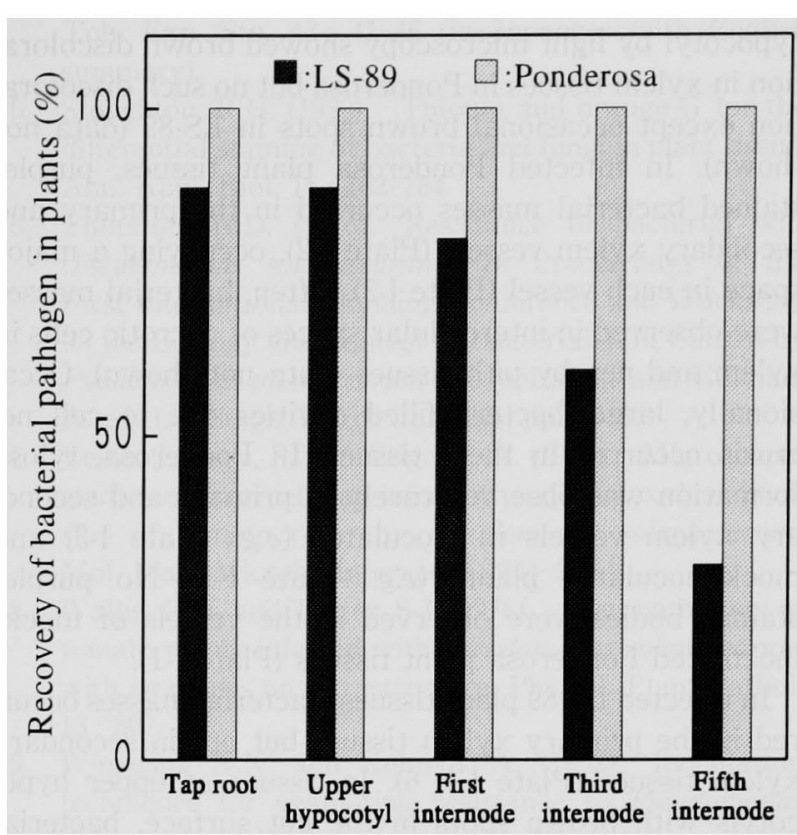

Fig. 3. Recovery of the pathogen from taproots and stems at the basal part to upper internodes of LS- 89 and Ponderosa at 14 days after inoculation with Ralstonia (Pseudomonas) solanacearum $8107 \mathrm{~S}$. Bacterial recovery was monitored on 912 randomly selected plants. Average of five replications.

from all taproot and stem sections tested in Ponderosa (Fig. 3). In LS-89, recovery was about $90 \%$ in taproots and upper hypocotyls, but gradually decreased in the upper internodes to reach $30 \%$ in the fifth internodes $(p<0.05)$.

\section{Distribution of the pathogen in stem tissues}

Cut surfaces of traverse sections from the upper

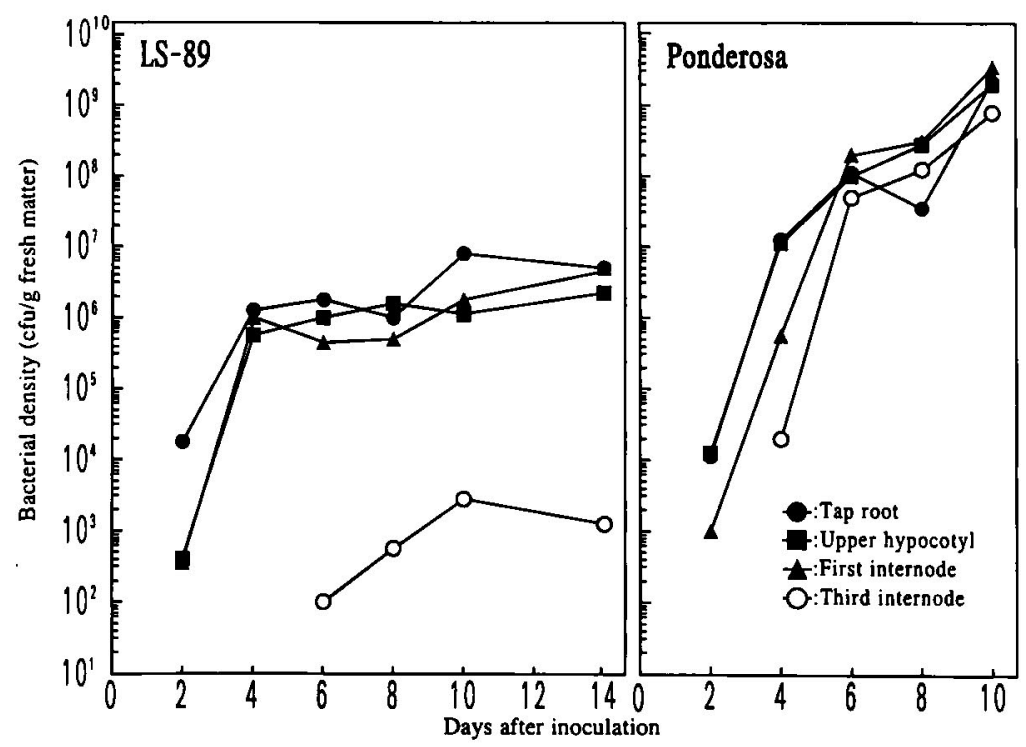

Fig. 2. Development of bacterial density in taproots and stems at the basal part to upper internodes of LS-89 and Ponderosa after inoculation with Ralstonia (Pseudomonas) solanaceanum 8107S. Bacterial density was monitored on 5-7 randomly selected plants. Average of five replications. 
hypocotyl by light microscopy showed brown discoloration in xylem tissues in Ponderosa but no such discoloration except occasional brown spots in LS-89 (data not shown). In infected Ponderosa plant tissues, purplestained bacterial masses occurred in the primary and secondary xylem vessels (Plate I-2), occupying a major space in each vessel (Plate I-2). Often, bacterial masses were observed in intercellular spaces of necrotic cells in xylem and nearby pith tissues (data not shown). Occasionally, large, bacteria-filled cavities due to cell necrosis occurred in these tissues. In Ponderosa, tylose formation was observed rarely in primary and second ary xylem vessels in inoculated (e.g., Plate I-2) and mock-inoculated plants (e.g., Plate I-1). No purplestained bodies were observed in the vessels of mockinoculated Ponderosa plant tissues (Plate I-1).

In infected LS-89 plant tissues, bacterial masses occurred in the primary xylem tissues but not in secondary xylem tissues (Plate I-4, 6). In tissues of upper hypocotyls with brown spots in the cut surface, bacterial masses were observed in primary xylem vessels and occasionally in surrounding necrotic cells (Plate I-6). Tissues of upper hypocotyls that showed no brown spots in the cut surface had bacterial masses in necrotic cells or intercellular spaces (Plate I-5). Generally, the size of bacterial masses in each xylem vessel was smaller in LS-89 than in Ponderosa (Plate I-2 and I-4). In infected LS-89, marked histological changes were not observed either in xylem or other tissues except for the bacterial masses in cells or intercellular spaces (compare Plate I-3 and I-6). In LS-89, tyloses formed in some vessels of the primary and secondary xylems, both in inoculated and mock-inoculated plants (data not shown). No bacterial masses were observed in xylem tissues in mockinoculated plant tissues (Plate I-3).

\section{DISCUSSION}

After inoculation with $R$. solanacearum $8107 \mathrm{~S}$ by the immersion of cut roots in a bacterial suspension of $10^{7}$ $\mathrm{cfu} / \mathrm{ml}$ and growth chamber for 14 days at $30^{\circ} \mathrm{C}$, almost all LS-89 plants had latent infection and all of inoculated Ponderosa plants had wilted. LS-89 plants showed no retardation in plant growth and no sign of abnormality in the level of respiration of plant tissues $\left(\mathrm{g} \mathrm{H}_{2} \mathrm{O} \mathrm{h}^{-1}\right.$ plant $^{-1}$ ) (data not shown). Pathogen density increased in infected taproots and stems of both cultivars, but to a lesser extent in LS-89 than in Ponderosa. The density was especially low in upper internodes in LS-89. In addition, the recovery of bacteria from latently infected LS-89 tissues was higher in the basal part of the stems than in the upper parts. These results, indicating that bacterial movement and multiplication is limited in stems of LS-89, agree with the results of Grimault and Prior $^{4}$. Limitation in movement and/or multiplication of bacterial wilt pathogens in plants has also been reported in resistant cultivars in other solanaceous crops, including potato ${ }^{1)}$, tobacco ${ }^{14)}$, eggplant and pepper ${ }^{5}$.

In our previous report on tomato ${ }^{13)}, R$. solanacearum moved from inoculated resistant LS-89 rootstocks into the susceptible Ponderosa scions and caused wilting. Wilting due to bacteria in susceptible Ponderosa scions grafted on LS-89 was milder than that in Ponderosa or LS.89 scions grafted on Ponderosa. Because of the limitation in both bacterial movement and multiplication in LS- 89 rootstocks, the movement of bacteria from rootstocks to scions may be less in number when LS-89 was used as the rootstock than when Ponderosa was used.

In this study, light microscopy of tissues samples collected from upper hypocotyls showed bacterial masses only in the primary xylem in LS-89, but in both the primary and secondary xylems in Ponderosa. Furthermore, the frequency of bacterial masses in vessels in transverse sections was high in Ponderosa, but low in LS-89. In tomato seedlings in which the secondary xylem had not been developed yet, bacterial colonization was observed in some vessels of the primary xylem in hypocotyls of partially wilted plants ${ }^{17)}$ and in the protoxylem and metaxylem (mainly in pitted vessels (metaxylem vessels) ${ }^{2)}$ ) in epicotyls of susceptible plants, as opposed to primarily in the protoxylem vessels in epicotyls of resistant plants ${ }^{6}$. The results in this study and earlier studies ${ }^{6,13,17)}$ indicate that $R$. solanacearum colonizes vessels of the protoxylem and primary and secondary xylem in susceptible cultivars, whereas it colonizes inner parts of the xylem, mainly the primary xylem, in resistant cultivars. The spread of the pathogen horizontally from the protoxylem or primary xylem tissues to other xylem tissues seems to be limited in resistant cultivars.

Wilting of plants infected with bacteria is likely induced by the blocking of water conductance resulting from mechanical plugging of xylem vessels ${ }^{3}$, as has also been described in bacterial wilt of tomato with vessels becoming plugged by bacterial masses ${ }^{10}$, extracellular polysaccharides ${ }^{9)}$ or tyloses ${ }^{18)} . R$. solanacearum -infected LS-89 escaped from wilting because bacterial masses were low in frequency and smaller in size in stem tissues.

Tylose formation in infected Ponderosa and LS-89 plants was essentially similar, inconsistent with the report of Grimault et al. ${ }^{6}$ ) correlating a limitation of bacterial spread in a resistant tomato with the production of tyloses in bacterial colonized and adjacent ves sels. Tylose formation may not be a necessary factor to limit bacterial movement. Why $R$. solanacearum does not multiply or migrate extensively in tissues of resistant plants remains to be clarified.

The author thanks Dr. A. Ohuchi, National Institute of Agro-Environmental Sciences and Dr. S. Takaya, formerly of Chugoku National Agricultural Experiment Station, for their helpful suggestions and encouragement, and Dr. $\mathrm{H}$. Hibino, Chugoku National Agricultural Experiment Station, for critical reading of the manuscript. 


\section{Literature cited}

1. Bowman, J.E. and Sequeira, L. (1982). Resistance to Pseudomonas solanacearum in potato: Infectivity titra. tions in relation to multiplication and spread of the pathogen. Am. Potato J. 59 : 155-164.

2. Esau, K. (1977). Anatomy of Seed Plants, 2nd ed., John Wiley \& Sons, New York, pp. 111-116.

3. Goto, M. (1992). Fundamentals of Bacterial Plant Pathology, Academic Press, San Diego, pp. 213-214.

4. Grimault, V. and Prior, P. (1993). Bacterial wilt resistance in tomato associated with tolerance of vascular tissues to Pseudomonas solanacearum. Plant Pathol. 42 : 589-594.

5. Grimault, V. and Prior, P. (1994). Invasiveness of Pseudomonas solanaceanum in tomato, eggplant and pepper : a comparative study. Eur. J. Plant Pathol. 100 : 259-267.

6. Grimault, V., Gelie, B., Lemattre, M., Prior, P. and Schmit, J. (1994). Comparative histology of resistant and susceptible tomato cultivars infected by Pseudomonas solanacearum. Physiol. Mol. Plant Pathol. 44 : 105-123.

7. Hara, H. and Ono, K. (1983). Ecological studies on the bacterial wilt of tobacco, caused by Pseudomonas solanacearum E.F. Smith. I. A selective medium for isolation and detection of Pseudomonas solanacearum. Bull. Okayama Tob. Exp. Stn. 42: 127-138 (in Japanese with English summary).

8. Hayward, A.C. (1991). Biology and epidemiology of bacterial wilt caused by Pseudomonas solanacearum. Annu. Rev. Phytopathol. 29 : 65-87.

9. Husain, A. and Kelman, A. (1958). Relation of slime production to mechanism of wilting and pathogenicity of Pseudomonas solanacearum. Phytopathology 48 : 155165.

10. Kelman, A. (1953). The bacterial wilt caused by Pseudomonas solanacearum. North Carolina Agric. Exp. Stn. Tech. Bull. 99 : 1-194.

11. Kobayashi, N. (1993). Biological and integrated control of tomato and eggplant bacterial wilt. Proc. Assoc. Plant Prot. Kyushu 39 : 18-26 (in Japanese with English summary).

12. Monma, S. and Sakata, Y. (1993). Inheritance of resistance to bacterial wilt in tomato. In Bacterial Wilt. Proceedings of an International Symposium (Hartman, G.L. and Hayward, A.C. eds.), Kaohsiung, Taiwan. ACIAR Proc. 45 : 149-153.

13. Nakaho, K., Takaya, S. and Sumida, Y. (1996). Conditions that increase latent infection of grafted or nongrafted tomatoes with Pseudomanas solanacearum. Ann. Phytopathol. Soc. Jpn. 62 : 234-239.

14. Ono, K., Hara, H. and Akazawa, J. (1984). Ecological studies on the bacterial wilt of tobacco, caused by Pseudomonas solanacearum E.F. Smith. V. The movement of the pathogen in tobacco plants. Bull. Okayama
Tob. Exp. Stn. 43: 41-46 (in Japanese with English summary).

15. Stoughton, R.H. (1930). Thionin and orange G for the differential staining of bacteria and fungi in plant tissue. Ann. Appl. Biol. 17 : 162-164.

16. Thurston, H.D. (1976). Resistance to bacterial wilt (Pseudomonas solanaceanum). In Proceedings of the First International Planning Conference and Workshop on the Ecology and Control of Bacterial Wilt Caused by Pseudomonas solanacearum (Sequeira, L. and Kelman, A. eds.), Raleigh, North Carolina, pp. 58-62.

17. Vesse, J., Frey, P. and Trigalet, A. (1995). Microscopic studies of intercellular infection and protoxylem invasion of tomato roots by Pseudomonas solanacearum. Mol. Plant-Microbe Interact. 8: 241-251.

18. Wallis, F.M. and Truter, S.J. (1978). Histopathology of tomato plants infected with Pseudomonas solanacearum with emphasis on ultrastructure. Physiol. Plant Pathol. $13: 307-317$.

19. Winstead, N.N. and Kelman, A. (1952). Inoculation techniques for evaluating resistance to Pseudomonas solanacearum. Phytopathology $42: 623-634$.

20. Yabuuchi, E., Kosako, Y., Yano, I., Hotta, H. and Nishiuchi, Y. (1995). Transfer of two Burkholderia and an Alcaligenes species to Ralstonia gen. nov.: Proposal of Ralstonia pickettii (Ralston, Palleroni and Doudoroff 1973) comb. nov., Ralstonia solanacearum (Smith 1896) comb. nov. and Ralstonia eutropha (Davis 1969) comb. nov. Microbiol. Immunol. 39: 897-904.

21. Yamakawa, K. (1978). Cultivar resistance to Pseudomonas solanacearum in tomato and eggplant. Shokubutsu Boeki (Plant Protection) 32: 197-200 (in Japanese).

\section{和 文 摘 要}

中保一浩：抵抗性トマト台木品種 LS-89 と感受性品種ポンデ ローザの植物体内での青枯病菌の分布と増殖

青枯病抵抗性トマト台木品種 LS-89 と感受性品種ポンデロー ザの植物体内における青枯病菌の分布と增殖を調べた。 $30^{\circ} \mathrm{C}$ の グロースチャンバー内で断根した 30 日苗を青枯病菌 $8107 \mathrm{~S}$ 墅 濁液 $\left(10^{7} \mathrm{cfu} / \mathrm{ml}\right)$ に浸漬し接種した。ポンデローザでは接種 14 日目のすべての主根, 茎部の試料から病原細菌が検出された。根 部, 茎部の青枯病菌密度は接種 10 日目には生重量 $1 \mathrm{~g}$ 当たり $10^{8}$ あるいは $10^{9}$ 個に増加した。一方, 接種した LS-89 は無病徵 感染し, 接種 14 日目の主根と肧軸上部ての青枯病菌の検出率は 90\%以上であった。茎からの検出率は第 1-2 葉間の荎部で約 $80 \%$ ありり位の茎部にいくに従い低下した(第 5-6 葉間の茎 部て $30 \%)$ 。青枯病菌密度は接種 4 日目に主根, 肧軸上部および 第 1-2 葉間の茎部において生重量 $1 \mathrm{~g}$ 当たり $10^{6}$ 個まで増殖し たが,その後は一定であった。胚軸上部の横断面の光顕観察によ り, 青枯病菌はポンデローザの一次および二次木部組織に広く 認められたが, LS-89 では一次木部組織の一部のみに分布して いた。以上の結果, 抵抗性 LS-89 では青枯病菌の一次木部組織で の局在化と植物体内での移行抑制が認められた。 


\section{Plate I}

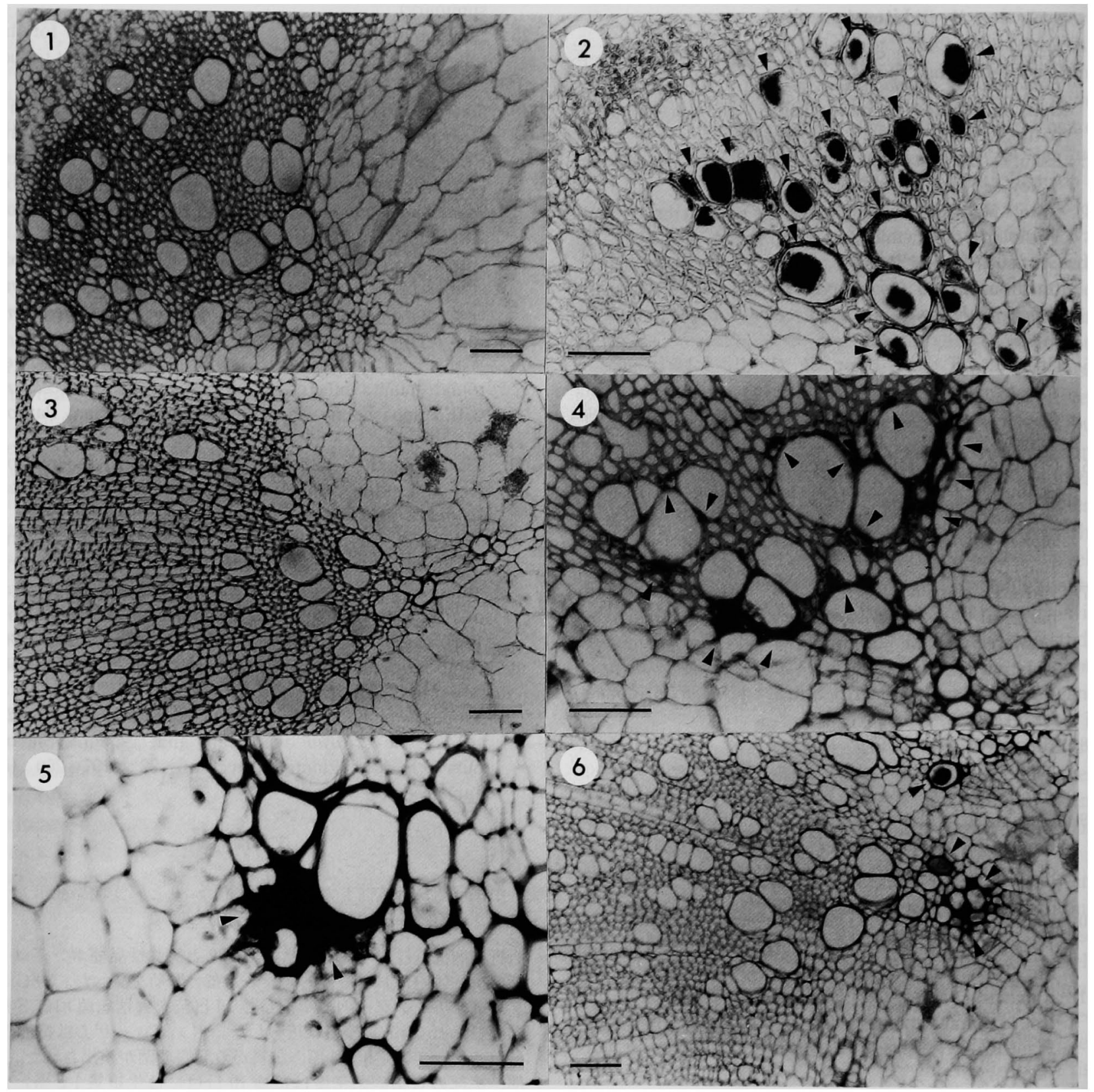

Plate I Transverse sections of the upper hypocotyls (approximately $5 \mathrm{~mm}$ below the cotyledon) in Ponderosa and LS- 89 plants inoculated or mock-inoculated with Ralstonia (Pseudomonas) solanacearum 8107S.

1. Mock-inoculated Ponderosa plant. Bar : $100 \mu \mathrm{m}$.

2. Wilted Ponderosa plant with bacterial masses (arrowheads) in primary xylem and secondary xylem vessels. Bar : 100 $\mu \mathrm{m}$.

3. Mock-inoculated LS-89 plant. Bar : $100 \mu \mathrm{m}$.

4. Inoculated LS-89 plant with bacterial masses (arrowheads) in the primary xylem. Bar: $100 \mu \mathrm{m}$.

5. Primary xylem in the upper hypocotyl of LS- 89 with bacterial masses (arrowheads) in necrotic cells or intercellular spaces. Bar : $100 \mu \mathrm{m}$.

6. Inoculated LS-89 plant with brown spots in cut surface has bacterial masses (arrowheads) in its primary xylem. Bar: $100 \mu \mathrm{m}$. 